\title{
SELF-CONFIDENCE IN ORAL PERFORMANCE
}

\author{
CAzimova M., Tashkent State Literature and Uzbek Language University, \\ Tashkent, Uzbekistan, Maftunazimova21@gmail.com
}

\section{УВЕРЕННОСТЬ В СЕБЕ ПРИ ИЗУЧЕНИИ АНГЛИЙСКОГО ЯЗЫКА}

\section{(САзимова М., Ташкентский государственный университет литературы и узбекского языка, 2. Ташкент, Узбекистан, Maftunazimova21@gmail.com}

Abstract. This article indicates the level of self-confidence during the oral performance of the students such as in speaking activities as well as the self-efficacy in their oral task achievements. Self-confidence is believed to be a psychological factor which has a considerable influence on students' speaking skills. The purpose of this article is identifying the student's selfconfidence conducting the students' survey on their self-confidence, in acquiring the English language with the help of questionnaire and students' responds are analyzed by the author.

Аннотащия. В статье рассматривается уровень уверенности в себе во время устных выступлений учащихся, таких как разговорная деятельность, а также самоэффективность в достижении устных заданий. Уверенность в себе является психологическим фактором, который оказывает значительное влияние на разговорные навыки студентов. Целью данной статьи является выявление уверенности студента в проведении опроса студентов об их уверенности в себе при изучении английского языка. Опрос проводился с помощью разработанного вопросника, а ответы студентов анализируются автором.

Keywords: self-efficacy, self-competence, self-assessment, psychological factor, case study.

Ключевые слова: самоэффективность, самооценка, психологический фактор, тематическое исследование.

\section{Introduction}

The English language is the most important in this modern society, as it is taught as a second language or foreign language in any countries. The spoken language is considered vital in the area of teaching language for many years. Brown and Yule [1] mentioned that the importance of the oral language as a subject for teaching had its own history. However, even after the end of the Second World War, it had an essential effect on teaching a foreign language. Speaking is the kind of ability which is mainly used in a particular language (Oxford Dictionary of English). The main aim of students who learn English as a foreign language is to enhance the speaking ability in order to achieve success in communicating with language accurately, fluently as well as effectively. In this following case study, the author observed the importance of self- confidence as a psychological factor which might effect on students' speaking performance while learning a foreign language. Moreover, the author paid attention to help the students to have positive attitudes toward their abilities for developing their level of success in the speaking skill. For this research four 10th grade students were chosen as well as wide varieties of approaches have been conducted. 


\section{Literature Review}

Four language skills such as speaking, listening, reading as well as writing, achievement of oral competence is highly correlated with confidence in itself people. According to Brown 'English language learners might not have ability to speak language or be expressed freely and fluently without a particular degree of self-confidence [2]. Enhancing the students' communicative ability is considered as one of the most complicated tasks in teaching languages. As Yashima and ZenuckNishide mentioned that practice of varieties range of communicative actions can improve confidence which is supposed to be essential factors and define willing of learners to take part in oral tasks in language classes [3]. Self-confidence is believed to be also a personal factor which plays vital and supporting role in achievement of a learning of a foreign language. Some researches claim that the process of acquiring language can be performed successfully without this expressive variable.

Besides, when there is a low level of a self-competence considered as an emotional constituent of self-confidence, acquiring knowledge of a foreign language is greatly affected, by the relationships between the student and a difficult task of learning another language that causes them to feel incapable "to be itself", speaking a modern language. Besides, there was agreement with above-mentioned information in the sense that "absence of students of confidence - especially sensitive area at school of preliminary elections, second studying as students are in age on development and doubts, and concern on themselves - more general feelings, than confidence or pride which appear from accumulation, also deeply personal knowledge inter [4].

According to the research learners may have imagination of themselves due to the feedback which they get from their peers in their lives, interacting a question to each other has positive influence on their self-confidence.

As Thompson mentions that parents and the members of family who have intensive interaction with their children as well as their peers and community play as role models, for instance sport celebrities trainers [5].

In addition, O'Brien offers that "any program installed to work when strengthening a children's self-assessment, has provided not menacing environment so that regardless of the fact that the feeling of control which they already possess hasn't been immediately eliminated". Some researchers believe that the environment that is safe contains wide varieties of aspects which deal with motivation stereotypes as well as feelings and it might have positive and negative impacts on learners' self-confidence [6].

Arnold states about the importance of influence form delivering of the lectures and even the acquisition of assessment in students' learning of foreign language as well as other essential factors and beliefs' theoretical concepts in enhancing learners' self-assessment were developed by Rosenberg and Branden [7].

In his book called "Building self-confidence with encouraging words" by the Master pointed that there are some important features in the students' self-confidence such as worrying and fear about their future and negative views related to their abilities as well as some beliefs that others feel responsibility for the events which happening to them. Apart from this, they believe that they are losing their own purpose and having no clear idea about their life can also lead to low level of selfconfidence. Some students never make an effort or try to be active and they believe that something bad will happen in their life. In addition, there are also some other factors such as they have destructive believes about unwillingness to succeed in their learning [8].

In comparison, Wright also states some characteristics of the learner with high level of selfconfidence and he categorized as: Those students do not see life as an ordinary existence and they try to achieve their goals with strong willing as well as they tend to set goals by themselves and 
attempt to achieve them with better results. They have a tendency to consider themselves as a successful than the learners with low self-confidence.

There are some possible suggestions by Juhana by stating that the effective key to the low level of self-confidence which has adverse effect on EFL learning mentioning that supporting students with motivation to make them feel self-confidence is not considered to be as an effective measurement . This survey proposes that teachers ought to be aware of learners' difficulties I oral performance in English classes. In addition to this, as McIntyre proposes that self-confidence has significant effect on willingness to have communication in a foreign language and also in order to have speaking skills as a native speaker, self-confidence is of the most important feature as lack of self- confidence might unlock communicative skills barriers [4].

\section{Participant Profile}

For this particular case study four students from Public school were selected. Two of them are males and others are females. Among learners there are mixed level of learners. Learners are in beginner and intermediate levels. Participants are named as A, B, C, D. All participants did not take part in English tutorial lessons, they were taught only at school. There are also beginners and preintermediate level of students. Taking consideration into some reasons, learning English as a foreign language, it would be possible to have lack of confidence about making mistakes at that time to communicate orally and to have interaction with others [7]. The purpose of this case study consists in checking confidence of students in interacting with each other.

The students which are chosen, they have been taught by teachers through grammar translation method and the audio lingual method. They have not experience in speaking to native speakers.

\section{Research Design}

In this particular research the interview was conducted by the author. The interview was divided into three aspects. The questions are related to "Speaking participation in the English class '(3 questions), 'Cognitive domain" (4 questions), and "Self -esteem" (6 questions). Additionally, in order to know the students' self-confidence, there were some questions based on " questionnaire of self -confidence", "The Rosenberg self-esteem scale" was chosen which contains questionnaire with possible answers and students are required to write on them "Agree", 'Disagree' 'Strongly agree", "'neither agree nor agree", "'Strongly disagree". The tenth grade of students from Public school are involved in this survey [9].

\section{Data collection and Findings}

Firstly, in order to examine the students' oral participation in the class, I took some questionnaire.

\section{"ORAL PERFORMANCE IN THE ENGLISH LESSON".}

Question 1: "Are you supported to speak English in class by your teacher? "'

A: "Yes, I participate actively in class and during the speaking activities"

B: "Yes, we tend to practice pronunciation and dialogues as well"

C: "Well, we are learning in class rarely"

D: "Yes it is very essential because that helps us to have a better pronunciation"

Question 2: How often do you use the English language ?

A: "I participate in class in every class"

B: "Only in my English classes"

C: "Only when I am asked by the teacher, and during speaking activities"

D: "Sometimes, among my close friends. I almost never speak, because the majority of my friends do not care or don't understand"

Question 3: Do your classmates support you to improve English speaking skill? 
A: "Yes, we improve in vocabulary and pronunciation helping each other"

B: "Yes, my friends explain me what I don't understand"

C: "Yes, but not often"

D: Not always. Generally, I am used to doing things by myself

COGNITIVE DOMAIN

"Question 4: Do you learn vocabulary and some expressions through contrast, comparison, or corresponding?

A: "Actually, we have few (repetitions) we have a lot of speaking drills and grammar rules, but not so many dialogues"

B: "Yes, every day we learn some words"

C: "Yes, speaking and interacting with others improve my vocabulary, because there are many words I didn't know"

D: "Yes, a lot"

Question 5: Is your class consisted of repetitions activities, like drills, dialogues, reciting rules and practicing patterns?

A: "Yes and they are very effective to learn"

B: "We have a lot of repetitions of topics until they are clear for us and oral projects"

C: "Yes, always, I like it"

D: "The use of interactive exercises helps us more than the grammar exercises"

Question 6: What is your opinion about the oral project?

A: "The presentation of oral projects help us with the pronunciation and the accent"

B: "The oral projects help us to improve pronunciation"

C. "I am fond of them, as I do things I had never done before, and that help me to overcome the fear and the panic I feel...!" language"

D. I am fond of them, as it's one of the best approach to put into practice the English

\section{SELF-CONFIDENCE:}

Through these questions I intend to find out how in confidence of students have effect on their speaking skill and communication with each other .

Question 7: Is it comfortable for you to speak English in front of the class ?

A: "Sometimes (not always )"

B: "No teacher, I think it's hard because I don't know to pronounce and they laugh at me!

C: "Not always, because I got panicked and I don't have a good pronunciation...!

D: "Yes, because, I have a clear accent and a good vocabulary"

Questions 8: How do you think other students and your teacher in class react when you make mistakes ?

A: "Some of them help me and correct me"

B: "They laugh at me and boo a lot, and start to criticize"

C: "They might laugh at each other and make enjoyment during presentations"

D: "Sometimes, we help each other"

Question 9: Are you a good English language student ?

A: "I think I have abilities for languages, but I have to work harder to improve speaking and listening"

B: "I am not good at all"

C: "Yes, I am good at English"

D: "Yes, I like it a lot, and I know that soon I will speak perfect English, not only English, but other languages" 
Question 10: What is your reaction when you have speaking activity in the classroom ?

A: "A little worry...! Because of the pronunciation"

B: "Well, if it is in group I react well, but if it is individual, I get really nervous"

C: "A little worry...! Because of the pronunciation"

D: "I get a little worried to present oral projects in front of others, but I work a lot to do it"

Question 11: Have you ever tried to present your projects working in a group and individually? Why ?
A: On my own, I like learning alone..."
B: "In group is easier..."
C: "I am more confident when I work in group"
D: "On my own"

\section{Analysis of Self-esteem}

It is specified that self-confidence - a personal factor which plays the supporting role in achievement of a learning of foreign language and that some researches claim that no language operations of studying will be performed successfully without this emotional variable [3]. In questions 7, 8, 9 it is noticed that all students need more strengthening to overcome their fear. In questions 8 they have told that it is a shame to them how they laugh and criticize them. In a question 9, they need some strengthening to overcome their fear. Considered 11 two students have answered that they liked to work individually, but other two students thought that it was easier, and they felt confidence working in team.

According to Phillips E when students work in groups, they often feel safer and are less self -conscious and embarrassed to speak out because reporting on a group response is less threatening than giving an answer for which only the individual student is responsible. In the oral projects to be presented in class, students will be given the option to work individual or as a group, because it is also important to consider individualities and preferences at the time to present any oral task. To improve cognitive abilities, some learning strategies that could be easily introduced in class include: teaching learners how to take notes or make vocabulary records, giving them the opportunity to guess unknown words from context, encouraging learners to ask when in doubt, and short interviews to provide students to interact orally. The use of such strategies could be included in the student's short term goals, and when learners perceive that these strategies help them complete a task more successfully, they can also improve their self-efficacy [4].

Then, I gave them this following questionnaire. FLCAS (Foreign Language Classroom Anxiety Scale) survey)

1. I have able to learn to speak English.

2. I consider myself as a good student.

3. In my team I am supposed to be an important member

4. My group wants me to come to the lesson every day.

5. I never feel shy while speaking English to my groupmates.

6. I have never felt shy when I speak English to my English teacher.

7. I never feel shy while I am speaking to other subjects' teachers at school.

8. I hope that I will speak fluent English someday.

9. I wish that I will get a better score one day.

10. I believe that I will receive a 5 in this class 
SELF-CONFIDENCE QUESTIONNAIRE RESULTS

\begin{tabular}{lcccc}
\hline Number of questions & Strongly agree & Agree & Disagree & Strongly disagree \\
\hline Question 1 & 2 & 4 & 6 & 3 \\
Question2 & 4 & 4 & 5 & 2 \\
Question3 & 2 & 3 & 5 & 5 \\
Question4 & 3 & 4 & 4 & 4 \\
Question5 & 2 & 3 & 5 & 5 \\
Question6 & 2 & 4 & 4 & 5 \\
Question7 & 5 & 4 & 3 & 3 \\
Question8 & 2 & 4 & 4 & 5 \\
Question9 & 3 & 3 & 5 & 3 \\
Question10 & 2 & 37 & 5 & 5 \\
\hline Overall answers & 27 & & 46 & 41 \\
\hline
\end{tabular}

\section{Analysis of self - confidence questionnaire}

In this following survey there were 10 questions about speaking skill of students. In this survey from 15 students there were 27 strongly agree, 37 agree, 41 strongly disagree, 46 disagree answers. As survey indicates that the high number shows strongly disagree and agree. The students showed lower self-esteem in speaking as well as in their achievements. If there is the higher confident, the higher performance the students will show.

\section{Data Collection and Findings}

Analysis: Oral participation in the English class.

In question 1, most of the students had repetition drills to improve pronunciation; moreover, they recognized the opportunity is given in a class to practice a speaking skill.

In questions 2 and $3 \mathrm{~A}, \mathrm{~B}, \mathrm{C}, \mathrm{D}$, has shown not any interests in speaking English in class and they said that they did not speak too much and they felt shyness. However, C and D participations had different thoughts and opinions that despite not anyone paid attention to it, they took part in class and took into account the changes which the teacher gave. A and B said that they took benefits from their friends as well as help from their teacher

In questions 4 and 5, almost all the students agreed that they have many mechanical pieces of training, repetitions, grammar rules and practising of vocabulary through metaphor, analogies, compare and matching exercises and the way they help them to develop and enhance their communication ability, and only two students; D claimed that the need for more dialogues to communicate with others. According to 6 questions all students answered that oral projects are very beneficial for their pronunciation and $\mathrm{C}$ answered that oral projects help overcome his fear and the panic that he feels. Participant A said that it can be helpful for their accent.

\section{Analysis of self - confidence questionnaire}

In this following survey there were 10 questions about speaking skill of students. In this survey from 15 students there were 27 strongly agree, 37 agree, 41 strongly disagree, 46 disagree answers. As survey indicates that the high number shows strongly disagree and agree. The students showed lower self-esteem in speaking as well as in their achievements. If there is the higher confident, the higher performance the students will show.

\section{Conclusion}

This case study examined low self-confidence and what kind of effects on oral in tenth grade of students in Public school. I found out that majority of students had low self-esteem despite they had good performance in learning the language however they often felt ashamed when it came to participate in class as the shyness provided them from participating. Moreover, all participants had some kind of fear and panic during the lesson while talking to teacher. Teacher should pay attention to every student who is extremely shy and feel low-confidence as they might not active in the lesson 
but they could be good learners. The teacher should encourage students to participate in every lesson paying more attention for them who are supposed to be not so active. From the research questions I realized that achieving success of students in learning the language according to their answers indicated low point as most of them thought that they had doubts to speak perfect English .As Brown stated that when there is low-esteem, the learners cannot speak and express themselves fluently (Brown 1996). I found that students showed low performance in speaking skill as they thought that they had not good pronunciation that's why they were not able to present oral presentation individually as well they had fear that their group mates laughed at them. The teacher should work on behavior of some students as it causes loose self-confidence in themselves. In addition, the pronunciation was main issue which led to low-esteem in oral performance. In conclusion, I would like to say that self -confidence is essential feature in producing good oral performance in class. The students are not able to show good results in speaking skills as well as learn the language effectively.

Questionnaire

\section{Appendix}

ORAL PARTICIPATION IN THE ENGLISH CLASS.

Question 1: " Does the teacher provide you opportunities to speak English in class? ",

A: "Yes, I have to participate in class and during the oral projects"

B: "Yes, we practice pronunciation and dialogues, that promotes learning"

C: "Well, little by little, we are learning in class"

D: "Yes, he does, and that is very important because that helps us to have good pronunciation"

Question 2: When do you speak English in class?

A: "Every time I participate in class"

B: "Only in my English classes"

C: "Only when the teacher asks, and during the activities"

D: "Sometimes, among close friends. I almost never do it, because the majority doesn't care or don't understand"

Question 3: Do your classmates help you to develop the speaking English skill?

A: "Yes, because when we help each other, we improve in vocabulary and pronunciation"

B: "Yes, my friends explain me what I don't understand"

C: "Yes, sometimes..."

D: Sometimes.... But in general I do things by myself

\section{COGNITIVE DOMAIN}

Question 4: Are you learning vocabulary and expressions through comparison, analogy, or matching?

A: "Actually, we have few (repetitions) we have a lot of speaking drills and grammar rules, but not so many dialogues"

B: "Yes, every day we learn some words"

$\mathrm{C}$ : "Yes, speaking and interacting with others improve my vocabulary, because there are many words I didn't know"

D: "Yes, a lot"

Question 5: Are your classes full of repetitions activities, such as drills, dialogues, reciting rules and practicing patterns?

A: "Yes and they are very effective to learn"

B: "We have a lot of repetitions of topics until they are clear for us and oral projects"

C: "Yes, always, I like it" 
D: "The use of interactive exercises helps us more than the grammar exercises"

Question 6: What do you think of the oral projects?

A: "The presentation of oral projects help us with the pronunciation and the accent"

B: "The oral projects help us to improve pronunciation"

C. "I like them, because I do things I had never done before, and that help me to overcome the fear and the panic I feel...!"

D. I like them, because it's the best method to practice the English language"

SELF-CONFIDENCE:

These following questions were asked to 10th grade students to know how the lack of confidence could affect their oral production and interaction among them.

Question 7: Do you feel comfortable when you speak English in front of the class?

A: "Sometimes (not always )"

B: "No teacher, I think it's hard because I don't know to pronounce and they laugh at me!

C: "Not always, because I got panicked and I don't have a good pronunciation...!

D: "Yes, because, I have a clear accent and a good vocabulary"

Questions 8: How do you think other students and your teacher in class react when you make mistakes?

A: "Some of them help me and correct me"

B: "They laugh at me and boo a lot, and start to criticize"

C: "They laugh and make fun of us during presentations"

D: "Sometimes, we help each other"

Question 9: Do you consider yourself a good English language student?

A: "I think I have abilities for languages, but I have to work harder to improve speaking and listening"

B: "I am not good at all"

C: "Yes, I am good at English"

D: "Yes, I like it a lot, and I know that soon I will speak perfect English, not only English, but other languages"

Question 10: How do you react when you have an oral language activity in the classroom?

A: "A little worry...! Because of the pronunciation"

B: "Well, if it is in group I react well, but if it is individual, I get really nervous"

C: "A little worry...! Because of the pronunciation"

D: "I get a little worried to present oral projects in front of others, but I work a lot to do it"

Question 11: How do you prefer to present your projects, work in a group, or alone? Why?

A: By myself, I like learning alone..."

$\mathrm{B}$ : "In group is easier..."

C: "I am more confident when I work in group"

D: "By myself"

\section{References:}

1. Horwitz, E. K., Horwitz, M. B., \& Cope, J. (1986). Foreign language classroom anxiety. The Modern language journal,70(2), 125-132. https://doi.org/10.1111/j.15404781.1986.tb05256.x

2. Brown, H. D. (1973). Affective variables in second language acquisition. Language learning, 23(2), 231-244. https://doi.org/10.1111/j.1467-1770.1973.tb00658.x

3. Brown, J. D. (2005). Testing in language programs: a comprehensive guide to English language assessement. McGraw-Hill College. 
4. Harmer, J. (2007). The practice of English language teaching. Harlow: Pearson Longman.

5. Hymes, D. (1972). On communicative competence. sociolinguistics, 269293, 269-293.

6. Canale, M., \& Swain, M. (1980). Theoretical bases of communicative approaches to second language teaching and testing. Applied linguistics, 1(1), 1-47. https://doi.org/10.1093/applin/I.1.1

7. MacIntyre, P. D., Baker, S. C., Clément, R., \& Conrod, S. (2001). Willingness to communicate, social support, and language-learning orientations of immersion students. Studies in second language acquisition, 23(3), 369-388. https://doi.org/10.1017/S0272263101003035

8. Rubio, R. A. (2007). Self-esteem and foreign language learning. Cambridge Scholars Publishing.

\section{Список литературы:}

1. Horwitz E. K., Horwitz M. B., Cope J. Foreign language classroom anxiety // The Modern language journal. 1986. Vol. 70 . №2. P. 125-132. https://doi.org/10.1111/j.15404781.1986.tb05256.x

2. Brown H. D. Affective variables in second language acquisition // Language learning. 1973. Vol. 23. №2. P. 231-244. https://doi.org/10.1111/j.1467-1770.1973.tb00658.x

3. Brown J. D. Testing in language programs: a comprehensive guide to English language assessement. McGraw-Hill College, 2005.

4. Harmer, J. (2007). The practice of English language teaching. Harlow: Pearson Longman.

5. Hymes D. On communicative competence // Sociolinguistics. 1972. Vol. 269293. P. 269293.

6. Canale M., Swain M. Theoretical bases of communicative approaches to second language teaching and testing // Applied linguistics. 1980. Vol. 1. №1. P. 1-47. https://doi.org/10.1093/applin/I.1.1

7. MacIntyre P. D. et al. Willingness to communicate, social support, and language-learning orientations of immersion students // Studies in second language acquisition. 2001. Vol. 23. №3. P. 369-388. https://doi.org/10.1017/S0272263101003035

8. Rubio R. A. Self-esteem and foreign language learning. Cambridge Scholars Publishing, 2007.

Работа поступила

в редакичю 08.03.2020 г.
Принята к публикациии 11.03.2020 2.

Ссылка для цүитирования:

Azimova M. Self-confidence in Oral Performance // Бюллетень науки и практики. 2020. T. 6. №4. C. 444-452. https://doi.org/10.33619/2414-2948/53/52

Cite as (APA):

Azimova, M. (2020). Self-confidence in Oral Performance. Bulletin of Science and Practice, 6(4), 444-452. https://doi.org/10.33619/2414-2948/53/52 